\title{
MATHESIS UNIVERSALIS A UNIVERSÁLNÍ METODA U DESCARTA
}

\author{
Jan Palkoska
}

Descartův projekt disciplíny zvané Mathesis universalis, ${ }^{1}$ představený kusým způsobem v Pravidle IV Regulae ad Directionem Ingenii (Pravidel pro vedení rozumu), ${ }^{2}$ nepřestává přitahovat zájem badatelů. Jediná pasáž, v níž Descartes kdy o Mathesis universalis hovoří ${ }^{3}$ - Pravidlo IV, AT X, 374.16-379.13 -, totiž tvoří závěrečný úsek Pravidla IV, jehož výchozí poučka zní, že „,ke zkoumání pravdy věcí je nutná metoda“, ${ }^{4}$ což se zdá zakládat předpoklad, že ohlášený projekt Mathesis universalis má co do činění s Descartovým projektem universální metody. ${ }^{5}$ A vzhledem

1 Jak by měl ukázat následující výklad, existují dobré důvody pro to, aby tento výraz zůstal nepřeložen. Zachovávám Descartův zvyk psát tento výraz s velkým písmenem na začátku, upouštím však od tradiční záměny (která se u Descarta samozřejmě zdaleka neomezuje na slovo universalis) „u“ $\mathrm{za}, \mathrm{v}^{\prime \prime} \mathrm{v}$ dochovaných rukopisných verzích textů Pravidel pro vedení rozumu. K problematice pramenné báze tohoto textu viz G. Crapulli, Introduction, in: R. Descartes, Regulce ad Directionem Ingenii: Texte critique établi par Giovanni Crapulli avec la version Hollandaise du XVIIème siècle, vyd. G. Crapulli, The Hague 1966, str. xi-xxxviii.

2 R. Descartes, Regulae ad Directionem Ingenii. Za standardní edici lze stále ještě považovat verzi v Euvres de Descartes, vyd. Ch. Adam - P. Tannery, I-XI, Paris 1897-1913, X (=AT X), str. 359-469, přestože zejména v př́ípadě Pravidel se jedná o edici kontroverzní (jak se na některých prŕíkladech ukáže níže). Překlady všech pasáží z tohoto spisu, stejně jako i všech ostatních citací, jsou mé vlastní.

3 Paulův a Tanneryho „Index général“ uvádí pod heslem Mathesis universalis (AT XII, str. 84) ještě některé další nepřímé výskyty, z nichž nejdůležitější je odkaz k Pravidlu VI (AT X, str. 384-385) a k Rozpravě o metodě, část 2 (AT VI, str. 19-20). Je zvláštní, že autoři zde opomíjejí zásadní místo z Pravidla XIV ( $A T$ X, str. 450-452) a celé Pravidlo XVIII.

4 Pravidlo IV (AT X, str. 371).

5 Descartův projekt universální metody musí zůstat v této studii v mnoha ohledech neanalyzovaný. Knihy a studie, které se tématu universální metody u Descarta věnují, jsou následující: Ch. Serrus, La méthode de Descartes et son application à la métaphysique, Paris 1933; L. Beck, The Method of Descartes: A Study of the Regulae, Oxford 1952, kap. 18; P. Schouls, The Imposition of Method: A Study of Descartes and Locke, Oxford 1980, kap. 4-5; D. Flage-C. Bonnen, Descartes and Method: A Search for a Method in Meditations, London 1999; J. Palkoska, 
k tomu, že navzdory Descartově silné rétorice zůstává celková povaha i konkrétní podoba universální metody, která je podle Descartových vlastních vyjádření při díle $\mathrm{v}$ jeho matematickém, př́rodovědeckém i metafyzickém myšlení, ${ }^{6}$ velmi nejasná a kontroverzní, představuje tedy Mathesis universalis jednu z prima facie nadějných možností, jak problematiku Descartovy universální metody rozklíčovat. Cílem předkládané studie je zjistit, zda a v jakém smyslu může Descartova Mathesis universalis těmto interpretačním záměrům vskutku posloužit. Přri pokusu o jeho dosažení se nechám vést otázkou, co přesně Descartes výrazem Mathesis universalis míní a jak se tento Descartův projekt vztahuje nebo může vztahovat k jeho projektu universální metody objevování.

V moderním bádání vykrystalizovaly tři hlavní linie interpretace toho, co Descartes míní výrazem Mathesis universalis v Pravidle IV. ${ }^{7}$ Lze je charakterizovat tvrzeními, že Mathesis universalis je koextenzivní (I) s obecnou algebrou jako fundamentální disciplínou na poli matematiky; (II) s matematickou artikulací materiální reality; anebo (III) s universální metodou objevování. ${ }^{8}$ Vzhledem k tomu, že matematika ve formě obecné algebry má podle Descarta představovat paradigma

The a priori in the Thought of Descartes: Cognition, Method and Science, Newcastle 2017, kap. 4.

6 Viz zejm. R. Descartes, Dopis Mersennovi, in: AT I, str. 349; Dopis Vatierovi, AT I, str. 559-560; Dopis neznámému adresátovi, in: AT I, str. 370.

7 Množství publikací k tématu od druhé poloviny 19. století do současnosti je ohromující, a není prostor věnovat se jim zde jednotlivě. Soustředím se na několik výkladových návrhů, které jsou všeobecně považovány za zásadní a bezprostředně umožňují vyjasnit mé vlastní stanovisko. Rozsáhlou bibliografii příspěvků k tématu do r. 1980 poskytuje F. Van De Pitte, Descartes's Mathesis Universalis, str. 74, pozn. 1 a J. Schuster, Descartes' Mathesis Universalis: 1619-28, in: S. Gaukroger (vyd.), Descartes: Philosophy, Mathematics and Physics, Sussex 1980, str. 80-81, pozn. 1-2. Pokud jde o důležité př́íspěvky po r. 1980, lze uvést alespoň P. Kraus, From Universal Mathematics to Universal Method: Descartes's Turn in Rule IV of the Regulae, in: Journal of the History of Philosophy, 21, 1983, str. 159-174; Ch. Sasaki, Descartes's Mathematical Thought, Dordrecht 2003, kap. 4, § 3 a kap. 8, § 1.; J. L. Doyle, How (not) to study Descartes' Regulae, in: British Journal for the History of Philosophy, 17, 2009, str. 3-30.

8 Různé podoby (I) jsou hájeny především v L. Liard, La méthode et la mathématique universelle de Descartes, in: Revue philosophique de la France et de l'étranger, 10, 1880, str. 569-600; J.-P. Weber, La Constitution du texte des Regulce, Paris 1964, kap. 1; J. Mittelstrass, The Philosopher's Conception of Mathesis Universalis from Descartes to Leibniz, in: Annals of Science, 36, 1979, str. 593-610; P. Kraus, From Universal Mathematics to Universal Method; Ch. Sasaki, Descartes's Mathematical Thought, kap. 4, § 3; interpretace (II) je prredstavena in: J. Schuster, Descartes' Mathesis Universalis; a výklad (III) je hájen především 
uplatňování universální metody objevování, ${ }^{9}$ obnáší zjevně každá z uvedených interpretací určité obecné implikace ohledně vztahu Mathesis universalis a Descartovy universální metody, přinejmenším v př́padě interpretací (I) a (II) lze nicméně tyto implikace dále specifikovat rozličnými způsoby. Budu hájit výkladovou linii (I) a pokusím se prokázat, že (II) a (III) jsou sice prima facie rozumné alternativy, je však namístě je odmítnout ve prospěch (I). Za tím účelem nejprve důkladněji představím výklad (I), který chci hájit, a podám argumenty na jeho podporu. Poté představím výklady (II) a (III), uvedu některé argumenty podávané v jejich prospěch a pokusím se ukázat, proč je třeba tyto výklady nakonec odmítnout. Na závěr podám svoji odpověd' na otázku po vztahu Descartovy Mathesis universalis k jeho projektu universální metody.

Ústřední pasáž obsahující prakticky vše, co Descartes kdy výslovně ř́íká o Mathesis universalis, zasluhuje ocitovat v úplnosti: ${ }^{10}$

„Když mne tyto myšlenky [o stopách opravdové mathesis v Pappovi a Diofantovi a o současné podobě algebry] přivedly od studia jednotlivostí v aritmetice a geometrii ke zkoumání jakési obecné mathesis, ptal jsem se nejprve, co přesně tím jménem všichni míní a [A] proč se jako o částech mathesis mluví nejen o uvedených dvou naukách, ale také o astronomii, hudbě, optice, mechanice a mnohých dalších matematických naukách. Nestačí zde přihlédnout k původu slova: protože totiž jméno mathesis znamená totéž co <latinské> disciplina, nazývaly by se $<$ i jiné nauky $>$ matematikou stejným právem, jako samotná geometrie. [B] Také vidíme, že každý, kdo byt’ i jen zavadil o školní práh, zcela bez obtíží rozliší v naskýtajících se oborech ty, které náležejí $\mathrm{k}$ mathesis, a ty, které náležejí $\mathrm{k}$ dalším naukám. Když jsem to uvážil pozorněji, zjistil jsem nakonec, že k mathesis se vztahují výhradně ty, v nichž se zkoumá uspořádání a míra, přičemž nezáleží na tom, zda se taková míra nachází v číslech, tvarech, hvězdách, zvucích, nebo v nějakém jiném předmětu; [C] že tudíž musí být nějaká obecná věda, jež by vysvětlovala vše, nač se lze ptát ohledně

v J.-L. Marion, Sur l'ontologie grise, Paris 1975, $\S \S 10-11$ a v F. Van De Pitte, Descartes's Mathesis Universalis.

9 Otázka, v jakém smyslu má být tato paradigmatická funkce realizována, je spletitější a nejasnější, než by se na první pohled zdálo, a nemohu se jí zde podrobně zabývat. Pro rozvinutější výklad viz J. Palkoska, The a priori in the Thought of Descartes: Cognition, Method and Science, oddíl 3.1.1.

10 Velká písmena v hranatých závorkách doplňuji pro lepší přehlednost následujícího výkladu. 
uspořádání a míry, aniž by se < řád a míra> připisovaly jakékoli speciální matérii; a že tato věda se označuje nikoli přejatým, nýbrž starobylým a zavedeným výrazem Mathesis universalis, protože je v ní obsaženo vše, díky čemu se i o dalších vědách říká, že to jsou části matematiky. ${ }^{11}$... [D] [J]ejí jméno je všem známo a všichni chápou, čím se zaobírá, a to dokonce i když se jí nevěnují..."12

Descartes, jemuž jde o nalezení opravdové mathesis, která by se díky své „dokonalé průzračnosti a snadnosti“"13 mohla stát paradigmatem jistoty ve vědách, se tedy nejprve $\mathrm{v}[\mathrm{A}]^{14}$ snaží určit, co mají společného všechny jednotlivé nauky souborně nazývané mathematicae (jako reprezentativní príklady jsou uvedeny složky pythagorejského quadrivia společně s optikou a mechanikou), protože právě díky tomuto hledanému společnému jsou správně charakterizovány jako „náležející k mathesis “ či jako „,̌ásti mathesis ${ }^{\text {“ }}{ }^{15} \mathrm{~V}[\mathrm{~B}]$ pak hledaný společný rys identifikuje se „zkoumáním uspořádání a míry“ a v [C] uvádí disciplínu, jejímž vlastním předmětem je ,vše, nač se lze ptát ohledně uspořádání a míry, aniž

11 Otázka správného překladu tohoto místa, a dokonce i správné podoby samotné původní latinské verze, je kontroverzní způsobem, který je vysoce relevantní pro téma této studie. Viz k tomu níže, zejm. pozn. 56.

12 Pravidlo IV (AT X, str. 377-378).

13 Tamt., str. 377.

14 Odtud dále odkazují velká písmena v hranatých závorkách k příslušně označeným úsekům naposledy citované pasáže.

15 Adam a Tannery vnesli do výkladu úseku [A] velký zmatek tím, že se oproti rukopisům rozhodli vložit čárku mezi slova complures a Mathematicae ve výrazu quare non modo jam dictce, sed Astronomia etiam, Musica, Optica, Mechanica, aliceque complures, Mathematicæ partes dicantur (AT X, str. 377,13-16; mé zvýraznění), takže příslušný český překlad by oproti uvedenému zněl ,,proč se jako o částech matematiky mluví nejen o uvedených dvou naukách, ale také o astronomii, hudbě, optice, mechanice a mnohých dalších naukách“. Souhlasím s F. Van De Pittem (viz Descartes's Mathesis Universalis, str. 66-67 a 77, pozn. 28; za tento důležitý výkladový bod vděčím právě tomuto autorovi), že ačkoli je taková emendace zjevně motivována snahou opravit porušený text (protože před nebo za slovem partes schází jméno v genitivu), jde zcela proti smyslu celé pasáže, který říká, že complures Mathematicae mají být označeny jako partes (Matheseos). Toto podle mne přirozené čtení nachází oporu i ve výpiskách A. Bailleta z Pravidel, přetištěných v $A T \mathrm{X}$, str. 484 (mé zvýraznění): „Les pensées qui lui vinrent sur ce sujet, lui firent abandonner l'étude particuliére de l'Arithmétique \& de la Géométrie, pour se donner tout entier à la recherche de cette Science générale, mais vraye \& infaillible, que les Grecs ont nommée judicieusement MATHESIS, \& dont toutes les Mathématiques ne sont que des parties." 
by $\mathrm{se}<$ řád a míra> připisovaly jakékoli speciální matérii“،, a přiřazuje jí název Mathesis universalis.

Tento obecný popis dění v citované pasáži představuje společnou bázi všech tří konkurenčních výkladů (I), (II) a (III). Zásadním sporným bodem, který ostře odděluje interpretace (I) a (II) na jedné straně od interpretace (III) na druhé straně, je pak otázka, zda „uspořádání a míra“, jejíž zkoumání je $\mathrm{v}$ [B] identifikováno jako hledaný společný rys, díky němuž jednotlivé mathematicae náležejí $\mathrm{k}$ mathesis, odkazuje $\mathrm{k}$ témuž jako „uspořádání a míra nepřipsané jakékoli speciální matérii“, které jsou v [C] identifikovány jako vlastní předmět Mathesis universalis. Interpretační linie (I) a (II) implikují kladnou odpověd', linie (III) pak odpověd' zápornou.

Mám za to, že kladnou odpověd' lze podepř́ít následujícími přesvědčivými argumenty. Za prvé, Descartes v [A] v rámci hledání společného rysu všech matematických disciplín uvažuje o původním významu

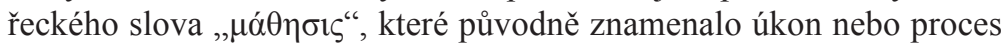
učení, postupem času se však začalo uživat ve významu „něčeho naučeného“, čemuž odpovídá latinské slovo disciplina (odvozené od discere, tj. učit se). ${ }^{16}$ Tuto etymologickou ekvivalenci však Descartes ihned zavrhuje jako neúnosně široké vymezení hledaného společného rysu, díky němuž všechny mathematicae právem spadají do oblasti mathesis, protože - jak poznamenává - potom by za mathematicae platilo cokoli, co se lze naučit. ${ }^{17}$ Tento postup zavazuje Descarta $\mathrm{k}$ tomu, aby výraz „mathesis“" spojoval (přinejmenším v [A] a [B]) s rysem náležejícím všemu, co platí za mathematicae, a - což je nyní klíčové - výhradně tomu, na rozdíl od všech ostatních oblastí možného vědění. Následkem toho odkazuje „uspořádání a míra“ v [B] ke společnému předmětu veškerých možných mathematicae, a výhradně k jejich společnému předmětu. Dále platí, že (i) úvahy v $[\mathrm{A}]$ a [B] Descartes provádí bezprostředně po ohlášení záměru zkoumat ,jakousi obecnou [generalis] mathesis“ (AT X, 377.11);18 že (ii) na začátku úseku [C] nejprve charakterizuje Mathesis universalis, již zamýšlí vzápětí uvést na scénu, jako „obecnou [generalis] vědu“; ${ }^{19}$ že

16 Spoléhám se zde na lingvistické poznámky v F. Van De Pitte, Descartes's Mathesis Universalis, str. 63.

17 I na tomto místě (AT X, str. 377.17-19) je text bohužel porušený (srv. AT X, str. 377, pozn. b). Pro naše účely je ovšem podstatné, že podaný výklad Descartovy argumentace je obecně přijímán i kritiky interpretačních linií (I) a (II).

18 Mé zvýraznění slova „obecnou“.

19 AT X, str. 378.4-5. Mé zvýraznění. 
(iii) k vlastnímu předmětu této obecné vědy odkazuje výrazem „uspořádání a míra“, tj. stejným význačným výrazem, jaký užívá už v [B]; a že (iv) k přechodu od [B] k [C] užívá spojku „tudíž“ [proinde], prričemž [B] a [C] od sebe odděluje pouze středník. To vše nasvědčuje kontinuitě co do tématu a odkazování natolik silně, že to již samo o sobě ustavuje silnou presumpci proti čtení (III), které tuto kontinuitu popírá.

Pro takovou presumpci však mluví i další argumenty. V druhé polovině úseku [C] Descartes tvrdí, že Mathesis universalis je „starobylý a zavedený výraz“, ${ }^{20}$ a v [D] dodává, že ,jméno [této vědy] je všem známo a všichni chápou, čím se zaobírá, a to dokonce i když se jí nevěnují“. ${ }^{21} \mathrm{Je}$ tedy nabíledni, že Descartes zamýšlí uživat výraz Mathesis universalis zavedeným způsobem, odkazujícím $\mathrm{k}$ tehdy běžnému pojetí vlastního předmětu Mathesis universalis. Zdaleka nejvýznamnějším dobovým proponentem zavedeného úzu, na nějž zde Descartes podle všeho naráží, je pak vlámský matematik Adriaan Van Roomen. ${ }^{22}$ Ten v jednom ze svých spisů uvádí Mathesis universalis způsobem, který se velmi podobá Descartově expozici v $A T \mathrm{X}, 377-378$ :

„Geometrii a aritmetice je společná věda, která pojednává kvantitu obecně jakožto měřitelnou. ... Existuje totiž jistá matematická věda, společná aritmetice a geometrii, k níž se vztahují vlastnosti všech kvantit, nebot' poměr je společný všem kvantitám, nejen abstraktním, jako jsou čísla a velikosti, ale také konkrétním, jako jsou časy, zvuky, hlasy, místa, pohyby, síly... Tvrzení <této společné vědy> a jejich důkazy... prŕísluší k Mathesis universalis... Pojmenujme tuto vědu první matematika či první mathesis..." ${ }^{23}$

20 AT X, str. 378.7-8.

21 AT X, str. 378.17-18.

22 Vazby mezi Van Roomenem a Descartem podrobně a přesvědčivě mapuje Ch. Sasaki, Descartes's Mathematical Thought, str. 267-70. Historii pojmu a termínu Mathesis universalis od 16. století dále podává v klasické studii G. Crapulli, Mathesis universalis: Genesi di una idea nel XVI secolo, Rome 1969.

23 A. Van Roomen, Apologia pro Archimede ad Clariss. virum Iosephum Scaligerum, In Archimedis circuli dimensionem Expositio \& Analysis. Exercitationes cyclica contra Iosephum Scaligerum, Orontium Finceum et Raymarum Ursum, in decem dialogos distinctce, 19-55, Würzburg (sic; ve skutečnosti publikováno v Ženevě) 1597 , str. 22-23. 
Zásadní je nyní, že Van Roomen v jednom ze svých ústředních spisů Universae mathesis idea ${ }^{24}$ jednoznačně tvrdí, že první mathesis je vědeckou variantou disciplíny označené jako „Všeobecná matematika“ (Universa mathematica), přičemž toto označení odkazuje, stejně jako mathesis u Descarta v úseku [B], k nejvyššímu rodu v rámci vědy o kvantitě, ${ }^{25}$ jehož rozsah pokrývá veškeré matematické disciplíny:

„Soubor matematických disciplín zahrnuje jak ty, které jsou opravdu matematické, tak ty, které lze označit jako kvazi-matematické. Opravdová matematika je jednak řídící neboli prvotní, jednak pomocná neboli mechanická. Řídící matematika se zaměřuje na zkoumání o kvantitách a je dvojího druhu - čistá a nečistá neboli smíšená. Čistá matematika zkoumá čistou neboli inteligibilní kvantitu. Smíšená matematika zkoumá smíšenou neboli smyslovou kvantitu. Čistá $<$ matematika> je opět dvojí - všeobecná [universalis] a speciální. Všeobecná je ta, která se zaobírá veškerou kvantitou, totiž logistika a prvni mathesis - ta první jako nástroj vědy, ta druhá jako věda. Speciální $<$ matematika $>$ je také dvojí, a to aritmetika a geometrie ..." ${ }^{26}$

První mathesis je tedy pro Van Roomena vědou a je universalis v tom smyslu, že - podobně jako u Descarta v Pravidle IV - „se zaobírá veškerou kvantitou“, a u Van Roomena jednoznačně spadá do domény čisté matematiky, takže rozhodně v žádném ohledu nepřekračuje hranice matematiky. A protože stejné místo vymezují pro Mathesis universalis i všichni ostatní myslitelé, které snad mohl mít Descartes v [D] na zřeteli, lze opět uzavřít, že „uspořádání a míra nepřipsané jakékoli speciální matérii““v úseku $[\mathrm{C}]$ je koextenzivní s „uspořádáním a mírou“ v [B].

Tento závěr konečně nachází oporu i v následující pasáži z Descartova dopisu Isaacu Beeckmanovi:

„Mám-li Ti zcela otevřeně vyjevit, oč usiluji, tak mi jde nikoli o Lullovu Ars brevis, nýbrž o zbrusu novou vědu, v níž by bylo možno řešit veškeré otázky, které kdy mohou být kladeny $\mathrm{v}$ rámci libovolného rodu kvantity, jak spojité, tak nespojité. “27

24 A. Van Roomen, Universa mathesis idea, qua mathematica universim sumptce natura, prostantia, usus et distributio brevissime proponuntur, Würzburg 1602 .

25 Viz tamt., str. 3.

26 Tamt., str. 14-15.

27 AT X, str. 156-157. 
Popis hledané „zbrusu nové vědy“ v této pasáži souhlasí s popisem $M a$ thesis universalis ve výše citované Van Roomenově Apologia pro Archimede. A Descartes výslovně ř́ká, že všeobecnost ohlášené vědy je relativní vůči doméně kvantit, ,jak spojitých, tak nespojitých“.

Je-li takto prokázáno, že Descartes označuje jako Mathesis universalis disciplínu v rámci domény matematiky, není těžké ukázat, že projekt Mathesis universalis v Pravidle IV s největší pravděpodobností spadá vjedno s jeho projektem obecné algebry. Pro naše účely postačí soustředit se na fakt, že klíčovým momentem Descartovy převratné koncepce obecné algebry jakožto matematické analýzy je pojímání závislostí obecných kvantit relevantních pro daný problém na bázi jejich postavení $\mathrm{v}$ řadách spojitých úměr a vyjadřování takto uchopených vztahů úměrnosti $\mathrm{v}$ algebraických rovnicích. ${ }^{28}$ Právě s ohledem na tuto koncepci Descartes ke konci Pravidla XIV nabízí následující klasifikaci „vztahů čili úměr“ mezi kvantitami: ${ }^{29}$

„Jsou... jen dva rody věcí, které jsou navzájem porovnávány, mnohosti a velikosti ... Je třeba si nyní uvědomit, že všechny vztahy, které mohou nastávat mezi jsoucny téhož rodu, spadají do dvou tř́d: jde bud' o uspořádání, nebo o míru.“" ${ }^{30}$

Dvě třídy „vztahů čili úměr“ v kontextu ustavení podmínek obecného algebraického pojednávání kvantit - uspořádání a míra - přesně odpovídají tomu, co Descartes v Pravidle IV určil jako vlastní předmět Mathesis universalis. A identifikaci projektu Mathesis universalis s projektem obecné algebry u Descarta potvrzuje i důležitá pasáž z 2. části Rozpravy o metodé:

„Viděl jsem, že přestože se předměty [všech jednotlivých věd, jež se souhrnně nazývají matematickými] liší, všechny tyto [jednotlivé vědy] se shodují v tom, že neuvažují o ničem jiném než o různých vztazích či poměrech, které se v jejich předmětech nacházejí, a domníval jsem se proto, že bude lepší zabývat se pouze těmito poměry obecně a klást je výhradně v těch předmětech, které by mi

28 Detaily Descartovy koncepce se zde nemůžeme zabývat. Podrobněji k tomu viz např. J. Palkoska, The a priori in the Thought of Descartes, oddíly 3.2.2-3.

29 O tom, že kontextem citované klasifikace je vskutku projekt obecné algebry, svědčí předcházející úseky Pravidla XIV, zejm. AT X, str. 440.16-27; 441.21-29; 447.13-21.

30 AT X, str. 450-451. 
umožňovaly poznávat tyto poměry co nejsnáze... Také jsem si uvědomoval, že k jejich poznání jsem někdy potřeboval uvažovat o každém zvlášt', jindy si je jen zapamatovat, anebo jich pojmout několik naráz, a domníval jsem se proto, že mám-li o nich lépe uvažovat zvlášt', měl bych je pojímat jakožto úsečky...; avšak že mám-li si je zapamatovat, anebo jich pojmout několik naráz, bude zapotřebí, abych je vyjádřil co možná nejkratšími znaky... “31

V druhé polovině pasáže mluví Descartes nade vší pochybnost o své obecné algebře, a první polovina se co do tématu i struktury nápadně podobá ústřední pasáži $A T \mathrm{X}, 377-378$. To umožňuje s velkou mírou jistoty uzavřít, že „vztahy či úměry“ v právě citované pasáži jsou koextenzivní s „uspořádáním a mírou“ v $A T \mathrm{X}, 378$ a že kontext, v němž jsou pojednávány, je kontext obecné algebry.

Obrat'me se nyní k výkladové linii (II), jejímž nejvýznačnějším zastáncem je John Schuster. ${ }^{32}$ Schuster souhlasí se zásadním bodem, který jej přibližuje k výkladu (I) a staví ho do ostrého protikladu vůči výkladu (III), totiž že pole působnosti Mathesis universalis nepřekračuje hranice matematiky. ${ }^{33} \mathrm{Na}$ druhou stranu ovšem Schusterův výklad stojí na zásadní tezi, která je s (I) neslučitelná, totiž že vlastní předmět Descartovy ohlášené Mathesis universalis jsou v konečném důsledku veškeré tělesné představy či obrazy (images), platící za rozlehlé míry (mensurae) vzhledem $\mathrm{k}$ nějakému parametru (dimensio), vzhledem k němuž lze o rozlehlých předmětech uvažovat jako o měřitelných pomocí rozlehlých předmětů. ${ }^{34}$ Podle Schustera tak do rozsahu působnosti Mathesis universalis nakonec spadá nejen aritmetika a geometrie, ale také to, co Schuster nazývá „fyziko-matematika“, tj. více či méně specializované fyzikální disciplíny, nakolik připouštějí matematickou artikulaci. ${ }^{35}$ Místo toho tedy,

31 AT VI, str. 20.

32 Viz zejm. J. Schuster, Descartes’ Mathesis Universalis. Sám Schuster považuje za prvního průkopníka svého čtení Jacoba Kleina; srv. J. Klein, Greek Mathematical Thought and the Origin of Algebra, přel. E. Brann, New York 1992², zejm. str. 197-203. Kleinova kniha vyšla původně v němčině v letech 1934 a 1936. Schuster svoji interpretaci poprvé představil ve své disertaci Descartes and the Scientific Revolution, 1618-1634: An Interpretation (disertace Princeton 1977).

33 Viz zejm. J. Schuster, Descartes' Mathesis Universalis, str. 43.

34 Viz tamt., str. 65-72. Koncepci dimensio přejímá Schuster z Descartova Pravidla XIV ( $A T$ X, str. 447).

35 Viz J. Schuster, Descartes' Mathesis Universalis, str. 65-66; 71; 79. Schuster uvádí jako př́iklady hudební teorii, hydrostatiku a mechaniku. 
aby jako vlastní předmět Mathesis universalis identifikoval nejobecnější společné rysy všech jednotlivých matematických disciplín - jak tomu chce výklad (I) -, identifikuje Schuster tento předmět se sjednocením předmětů všech jednotlivých matematických disciplín, nakolik příslušné míry uplatňované $\mathrm{v}$ jednotlivých disciplínách připouštějí traktování na bázi algebraické analýzy. ${ }^{36}$

Schuster ukazuje, že tato koncepce je výsledkem Descartovy snahy o legitimizaci jeho raného projektu Mathesis universalis tím, že „předmětům všeobecné matematiky poskytne ontologické osvědčení a ukáže, $\mathrm{v}$ čem přesně spočívá jistota operací $\mathrm{v}$ rámci všeobecné matematiky“ ${ }^{37}$ Druhý z uvedených záměrů - ustavení jistoty operací - vyústil podle Schustera do koncepce základních algebraických operací jako reprezentovaných „logistikou rozlehlých symbolü“, tj. určitými konkrétními tělesnými představami, ${ }^{38}$ získanými abstrakcí z jednotlivých materiálních věcí a zpracovávanými veskrze průzračným způsobem $\mathrm{v}$ představivosti. ${ }^{39}$ A první z uvedených „legitimizačních“ záměrů - poskytnutí ontologického osvědčení - podle Schustera vyústilo do Descartova pokynu převést

„to, o čem chápeme, že to platí o velikostech obecně, na ten druh velikosti, který je v naší představivosti vykreslován ze všech nejsnáze a nejrozlišeněji; tím je však reálná rozlehlost tělesa, u níž se abstrahuje od všeho kromě toho, že má tvar...".40

Nechci rozporovat, že Schuster tematizuje zásadní uzlové body Descartových snah o ustavení epistemologických podmínek provozování matematiky a jak epistemologických, tak ontologických podmínek matematického traktování materiální reality. Mám nicméně za to, že Schusterovi se nepodařilo náležitě prokázat, že tyto uzlové body je na místě chápat jako realizaci Descartova raného projektu Mathesis universalis představeného v Pravidle IV. Prima facie je totiž dokonce možné argumentovat pro to, že uvedené uzlové body nelze vykládat tak, jak navrhuje Schuster: viděli jsme, že Mathesis universalis je v Pravidle IV charakterizována

\footnotetext{
36 Viz zejm. tamt., str. 71-72.

37 Tamt., str. 59.

38 V Pravidlech jde o úsečky a pravoúhelníky, v Rozpravě o metodě a v Geometrii již pouze o úsečky.

39 Viz J. Schuster, Descartes’ Mathesis Universalis, str. 64-65.

40 Pravidlo XIV (AT X, str. 441).
} 
jako věda, ,jež by vysvětlovala vše, nač se lze ptát ohledně uspořádání a míry, aniž by se <rád a míra> pripisovaly jakékoli speciální matérii“". ${ }^{41}$ Schusterův návrh je s touto charakterizací v přímém rozporu, nebot' naopak přiřazuje k Mathesis universalis tolik „speciálních matérii““, kolik je měr př́stupných matematickému zacházení. Protože neexistuje žádný př́mý textový doklad o tom, že by Descartes citovanou charakteristiku v pozdějších fázích Pravidel revidoval a začal výrazem „Mathesis universalis" označovat to, co by Van Roomen a další nazývali universa Mathesis,${ }^{42}$ je zjevně na Schusterovi, aby tuto textovou presumpci vyvrátil nějak nepřímo.

Jediný Schusterův pokus v tomto směru spočívá v tom, že klade podstatnou vazbu mezi - na jedné straně - Descartovým pojímáním jistých produktů tělesné představivosti jako nepostradatelných nástrojů, jež jsou čisté chápavosti nápomocny, aby se vyvarovala určitých chybných ontologických extrapolací způsobených směšováním abstraktivních operací opominutí (omissio) a vyloučení (exclusio), a mezi - na druhé straně - určitými produkty tělesné představivosti, totiž těmi, jež mají co činit s abstrahovanou rozlehlostí oplývající tvarem, ${ }^{43}$ jako (nepostradatelnými?) nástroji, jež jsou nápomocny čisté chápavosti při operacích týkajících se velikostí obecně. Avšak nakolik dohlížím, žádná taková podstatná vazba mezi obojím nenastává: jedna věc je tvrdit, že nemá-li čistá chápavost sejít na scestí při provádění operací s obecnými kvantitami, musí být př́islušné ideje doprovázeny určitými tělesnými představami - totiž představami úseček, popř. pravoúhelníků - odvozenými z abstrahované rozlehlosti mající tvar, a úplně jiná věc je tvrdit, že mají-li se prokázat pravdy matematiky související s obecnými kvantitami, je třeba zajistit si určité tělesné představy - tentokrát rozlehlé míry relativně $\mathrm{k}$ parametrům - odvozené opět $\mathrm{z}$ abstrahované rozlehlosti mající tvar. Druhé z těchto tvrzení může platit, i když neplatí první, a vice versa. Uzavírám tedy, že Schusterovi se nepodařilo doložit radikální rozšíření

\footnotetext{
41 AT X, str. 378; mé zvýraznění.

42 Na Schusterovo latentní směšování dvou oborů, které Van Roomen a další striktně oddělovali, totiž universalis mathesis a universa mathesis, správně upozorňuje Ch. Sasaki, Descartes's Mathematical Thought, str. 201-202. Jde o směšování všeobecnosti ve smyslu atributu disciplíny, jejímž předmětem je společná část předmětů všech ostatních matematických disciplín, a všeobecnosti v kolektivním smyslu, tj. jakožto atributu souboru, který je sjednocením všech předmětů všech jednotlivých matematických disciplín. Viz též G. Crapulli, Mathesis universalis: Genesi di una idea nel XVI secolo, Rome 1969, str. 8.
}

43 Ve smyslu výše citované pasáže z Pravidla XIV (AT X, str. 441). 
rozsahu předmětů Mathesis universalis, které je pro jeho výklad rozhodující, a že jeho interpretační návrh (II) je tudíž třeba odmítnout.

Přejděme nyní k výkladové linii (III) a sledujme, zda si povede lépe. Ústřední teze této linie zní, že program Mathesis universalis v Pravidle IV je koextenzivní nejen s programem obecné algebry, nýbrž s programem dokonale universální metody objevování. Budu se soustředit na zřejmě nejvlivnější a také nejjasněji podanou verzi načrtnuté pozice $\mathrm{v}$ textech Jeana-Luca Mariona a Fredericka Van De Pitteho. ${ }^{44}$

Marion má za to, že jakkoli se disciplína, již Descartes označuje jako Mathesis universalis, zabývá tím, co je společné všemu matematickému, její vlastní předmět se neomezuje pouze na matematično. Podle Mariona je tomu tak proto, že Descartova Mathesis universalis se zabývá „,nematematickou matematičností matematična“"45 a jako taková není disciplínou v rámci matematiky (jak je tomu např. u Van Roomena), nýbrž jedná se spíše o ,jedinou vědu produkující všeobecnou jistotu způsobem, který je rovnomocný v nekonečnu indiferentních předmětů“", což je věda, jíž podle Mariona náleží označení „obecná metoda“. ${ }^{46}$ Marion tak tvrdí, že v Descartových rukách - na rozdíl od Aristotela, Prokla či Jamblicha - se Mathesis universalis emancipuje od toho, co Marion nazývá „,všeobecná matematika“" (mathématique universelle) a co podle všeho spadá vjedno s první mathesis jakožto nejbližším druhem rodu čisté matematiky ve Van Roomenově výše citované klasifikaci; ${ }^{47}$ „všeobecná matematika,“ píše Marion, „může zůstat všeobecnou jen tak, že zůstane matematikou; Mathesis universalis se stává všeobecnou jen díky tomu, že už není pouhou matematikou. “48 Uspořádání a míra, které podle výkladových

44 Budu vycházet z J.-L. Marion, Sur l'ontologie grise, Paris 1975; a z F. Van De Pitte, Descartes's Mathesis Universalis, in: Archiv für Geschichte der Philosophie, 61, 1979, str. 154-174; reprint in: G. Moyal (vyd.), René Descartes: Critical Assessments, I, London 1991, str. 61-79; cituji dle stránkování této přetištěné verze. Van De Pitte (Descartes's Mathesis Universalis, str. 61 a str. 74-75, pozn. 1-2) označuje za první proponenty variant přítomné výkladové linie následující autory: P. Boutroux, L'imagination et les mathématiques selon Descartes (Paris 1900); E. Cassirer, Descartes: Lehre, Persönlichkeit, Wirkung (Stockholm 1939); J. Beck, The Method of Descartes: A Study of the Regulae (Oxford 1952); a A. Balz, Descartes and the Modern Mind (Hamden 1967).

45 J.-L. Marion, Sur l'ontologie grise, str. 62 a 64; veškeré překlady pasáží z Marionova a Van De Pitteho textu jsou mé vlastní.

46 Tamt., str. 62.

47 A. Van Roomen, Universae mathesis idea, str. 14-15; citováno výše, str. 47.

48 J.-L. Marion, Sur l'ontologie grise, str. 64. 
linií (I) a (II) náležejí výhradně do oblasti matematiky, se podle Mariona stávají východiskem další řady odstupňovaných abstrakcí, během nichž původně kvantitativní kategorie uspořádání a míry překračují oblast matematiky a jsou pojednávány analogickým způsobem, jehož hraničním př́padem je pojetí uspořádání a míry jako nejobecnějších hledisek při určování ,jsoucna, nakolik je jsoucí“.49

Marion podle všeho předkládá tuto interpretaci jako určitou spekulativní možnost integrovanou do širšího rámce jeho dekonstrukční hermeneutiky uplatňované na Descartův text. Van De Pitte z Mariona výslovně vychází, předváděnou výkladovou linii však zásadně obohacuje jednak tím, že vyjasňuje souvislost mezi marionovsky interpretovanou Mathesis universalis a universální metodou, jednak - což je ještě důležitější - tím, že uvádí prímou argumentaci ve snaze vypořádat se $\mathrm{s}$ bezprostředním historickým kontextem Descartovy koncepce Mathesis universalis.

Podle Van De Pitteho má Descartova údajná koncepce Mathesis universalis jakožto překračující hranice matematiky zdroj v tom, že Descartes bere vážně dva úzce související závazky implikované ve Van Roomenově pojetí první mathesis: za prvé, že Mathesis universalis se $\mathrm{k}$ předmětům a principům všech ostatních matematických věd má stejně, jako se první filosofie má $\mathrm{k}$ předmětům a principům všech ostatních věd - totiž tak, že zahrnuje jejich předměty a dokazuje jejich principy; ${ }^{50}$ a za druhé, že jelikož je Mathesis universalis charakterizována tímto způsobem, je soběstačná (self-contained) v tom smyslu, že její vlastní principy náležejí výhradně jí samotné. ${ }^{51}$ Podle Van De Pitteho Descartes postřehl, že tyto dva závazky vzaté společně jsou neslučitelné s chápáním první mathesis, a potažmo Mathesis universalis, jako druhu v rámci matematiky:

„Je-li první mathesis pojímána jako nejzákladnější principy týkající se kvantity, stále je nutné brát v úvahu principy, které jedině vysvětlují, jak to, že otázky týkající se kvantity vůbec vyvstávají. ... Tradice tak [podle Descarta] stojí tváří v tváŕ dilematu: bud' je první mathesis druhem $\mathrm{v}$ rámci matematiky - $\mathrm{a} v$ tom př́padě není soběstačná ..., protože se musí vztahovat $\mathrm{k}$ ještě základnějším principům; anebo je

49 Tamt., str. 66.

50 Srv. A. Van Roomen, Apologia pro Archimede, str. 23.

51 Srv. A. Van Roomen, Universae mathesis idea, str. 20-21. 
soběstačná..., a tedy mimo matematiku, protože logicky předchází všem otázkám týkajícím se kvantity. “52

Proto je Descartes podle Van De Pitteho ochoten klást zásadní rozlišení

„mezi uspořádáním a mírou, nakolik se vztahují ke kvantitě, a na druhé straně mezi základnějšími principy uspořádání a míry, které jsou logicky dřívější a spadají mimo matematiku. V prvním případě jde o mathesis, $\mathrm{v}$ druhém prípadě o Mathesis universalis". 53

I podle Van De Pitteho samého je jednou z Descartem uvažovaných možností, jak předložené dilema vyřešit, omezení dosahu požadavku soběstačnosti Mathesis universalis jen na oblast matematiky. Právě takto se k věci staví Van Roomen a většina jeho zainteresovaných současníků. ${ }^{54}$ Hlavní problém Van De Pitteho argumentace tkví podle mého názoru v tom, že se mu (nakolik dohlížím) nedaří nezávislým způsobem prokázat, že Descartes toto standardní dobové řešení uvedeného dilematu skutečně odmítá, a přichází namísto toho s „marionovskou“ koncepcí Mathesis universalis. Nelze popřít fakt, že jakmile padne rozhodnutí číst Pravidlo IV optikou právě představené výkladové linie, lze většinu toho, co se píše o Mathesis universalis, interpretovat podobně hladce a soudržně jako na pozadí čtení v intencích výkladové linie (I). Ukázal jsem nicméně, že v Pravidle IV jsou pasáže, jejichž výklad silně podporuje linii (I) a jde proti linii (III); a naproti tomu ani v Pravidle IV ani jinde v Descartových textech nenacházím žádnou pasáž, která by jednoznačně podporovala (III) a šla proti (I). Vezme-li se do úvahy textová báze spolu s př́mým historickým kontextem Descartova pojednání Mathesis universalis, je proto nakonec na místě upřednostnit (I) před (III). ${ }^{55}$

52 F. Van De Pitte, Descartes's Mathesis Universalis, str. 64.

53 Tamt., str. 68.

54 Viz G. Crapulli, Mathesis universalis, kap. 7; Ch. Sasaki, Descartes's Mathematical Thought, str. 356.

55 Van De Pitte má za to, že dané břímě dokazování může unést. Upozorňuje, že na konci úseku [C] byl v edici Adama a Tanneryho vypuštěn ampersand mezi scientiae a Mathematicae navzdory tomu, že je přítomen jak ve verzi A, tak ve verzi $\mathrm{H}$ Pravidel, a tvrdí, že je-li ampersand znovu vepsán, je celou pasáž třeba číst nikoli tak, že „,v Mathesis universalis ... je obsaženo vše, díky čemu se o ostatních vědách ř́iká, že jsou částmi matematiky“ (F. Van De Pitte, Descartes's Mathesis Universalis, str. 69), nýbrž spíše tak, že „v Mathesis universalis... je obsaženo vše, díky čemu se o ostatních vědách včetně matematických říká, že to jsou její části“ (tamt.). Je-li 
Pokusil jsem se prokázat, že existují dobré textové i historické důvody pro výkladovou linii (I), podle níž je Descartův projekt Mathesis universalis koextenzivní s jeho projektem obecné algebry jako fundamentální disciplíny na poli matematiky. Tato interpretace nicméně bohužel implikuje, že chceme-li nějak rozklíčovat a informativně popsat povahu Descartem ohlašované universální metody, je přihlížení k Descartovu projektu Mathesis universalis k ničemu. Nejde ani tak o to, že tento projekt podle navržené interpretace spadá vjedno s projektem obecné algebry - zdá se totiž, že právě obecná algebra slouží Descartovi jako vzorový př́klad universální metody při díle a jako taková může při explikaci Descartovy universální metody dobře posloužit. Spíše jde o to, že zatímco pasáže, v nichž Descartes píše o své obecné algebře, vrhají na pasáže, v nichž Descartes píše o Mathesis universalis, nezanedbatelné světlo, opačně tomu tak zřejmě není. Chceme-li se dobrat podstaty Descartovy universální metody, je tedy snad načase spekulace o povaze Descartova projektu Mathesis universalis opustit a obrátit se jinam. ${ }^{56}$

\section{ZUSAMMENFASSUNG}

Ziel der Studie ist die Beurteilung der Annahme, dass das von Descartes angekündigte Projekt einer Mathesis universalis zur Erläuterung des unklaren und kontroversen Projekts einer universalen Denkmethode sowie zum Verständnis des generellen Begriffs der menschlichen Rationalität behilflich sein kann. Der Verfasser untersucht drei generische und sich selbst widersprechende Interpretationen dessen, was Descartes mit seiner

pasáž vskutku správné číst takto, pak Van De Pitte přichází se silným argumentem pro výklad (III): nakolik by všechny matematické vědy platily za části Mathesis universalis, nemohla by Mathesis universalis platit za druh v rámci matematických disciplín. Souhlasím s Van De Pittem, že k vypuštění ampersandu není žádný dobrý důvod. Mám nicméně za to, že opravená (vlastně restaurovaná) latinská podoba (quoniam in [Mathesi vniversali] continetur illud omne, propter quod alice scientice $\&$ Mathematica partes appellantur) připouští i jiné čtení, které je v dokonalém souladu s (I) a v rozporu s (III), totiž ,v Mathesis universalis ... je obsaženo vše, díky čemu se i o dalších vědách říká, že to jsou části matematiky“. Nejde mi o to dokázat za každou cenu, že mnou navržené čtení je přriměřenější než čtení Van De Pitteho. Postačuje mi držet, že jde o rovnocenné alternativy; tím se totiž neutralizuje jediný přímý textový argument pro zrušení výše ustavené presumpce pro čtení (I), který u Van De Pitteho nacházím.

56 Tato studie vznikla v rámci plnění grantového projektu GA ČR 16-12624S Pojetí pojmu v kontextu moderního myšlení. 
Mathesis universalis meinte, und zieht Schlüsse hinsichtlich des Bezugs von Mathesis universalis und des Projekts einer universalen Methode. Keineswegs ist die Mathesis universalis mit dem Projekt einer mathematischen Artikulation der materiellen Wirklichkeit oder einer universalen Denkmethode deckungsgleich. Eher ist sie eine weitere Bezeichnung von Descartes' spezifischem Begriff einer allgemeinen Algebra als der fundamentalen Disziplin auf dem Felde der Mathematik. In Anbetracht dessen sind die Aussichten auf eine Klärung der universalen Methode Descartes’ mithilfe des Begriffs „Mathesis universalis“ düster.

\section{SUMMARY}

The aim of the study is to assess the merits of a common assumption that the project of Mathesis universalis, announced by Descartes in Rule IV of his Regulae, could shed light on Descartes's notoriously unclear and controversial project of universal method of cognition, and by implication on his general notion of human rationality at work. The strategy is to consider three generic and mutually conflicting interpretations of what exactly Descartes meant by Mathesis universalis in the Regulae, and to draw consequences concerning the professed connection between Mathesis universalis and the project of universal method in Descartes. I argue that far from being co-extensive with either the project of mathematical articulation of material reality or the project of universal method of discovery, Mathesis universalis is just another name for Descartes's peculiar notion of general algebra as the fundamental discipline in the field of mathematics; and that this being so, the prospects of clarification of universal method in Descartes via his notion of Mathesis universalis are dark. 